\title{
The development of adjective and adverb grading in Romanian
}

\author{
Ștefan Găitănaru* \\ Faculty of Letters, University of Pitești, Str. Gh. Doja 41, 110253 Pitești, Romania
}

\section{Article info}

History:

Received April 28, 2014

Accepted June 29, 2014

Published January 13, 2015

Key words:

grading

intensifier

reverse superlative

analytic

synthetic

\begin{abstract}
The comparison of adjectives and adverbs has been described following the directions of evolution in Vulgar Latin, as well as the integrative trends in the context of the Romance languages, but without a detailed analysis. Leaving apart the theoretical goals, the present study is based on an updated understanding of the concepts involved in the category of grading, according to which it describes language constructions in the first three centuries texts. The main goal was giving examples of language constructions for the following types and subtypes of structures and elements: degrees of intensity (positive, intensive and absolute superlative), degrees of comparison (comparative of equality, comparative of superiority, comparative of inferiority and relative superlative); comparative semi-adverbs and means of expressing the comparative adverbial, as well as the extension of this syntactic position at the complex sentence level. After pointing out some regressive experiments, we tried to make a detailed and thorough correlation between the norms in the periods that were studied and the norm of contemporary standard Romanian.
\end{abstract}

\section{Preliminaries}

An overall description of the way that the category of grading has been expressed in Old Romanian, during a three century period (the $16^{\text {th }}$ century - the first half of the $18^{\text {th }}$ century), is necessary because the studies in the history of language and the linguistic researches on certain edited texts do not manage to examine the diversity of this issue.

It has to be pointed out that the theoretical aspects involved in this category are not entirely explained in the existent grammar researches. In some previous studies (cf. Găitănaru, 2013), the research has been based on the synchronic study of language; at that moment, some confirmations coming from the Old Romanian were necessary.

The present paper barely approaches the theoretical aspects, but it is focused on the complex means used to express the adjective and adverb gradation, both at the sentence (morphological and syntactic) level and at the complex sentence level.

A delimitation of the described language samples according to the century they belong to, in the context of multiple examples, was possible, but we preferred to quote diversified texts belonging to different periods, as this approach enlightens as to the continuity of the process.

The diachronic structures that have been described are the fundamental ones and they generally range into the coordinates which are established by comparing the norms of the respective period with the contemporary norm.

\section{Latin}

With adjectives and adverbs, there is a great difference to be noticed between the means of expressing the category of grading in Classical Latin and Romance languages (the situation is similar with Romanian,

*Email address: stefan_gaitanaru@yahoo.com. 
Ștefan Găitănaru

which is rather conservative due to the fact that it is situated in a lateral area). This happens because the system of Classical Latin was destabilised from inside, according to a determined structural dynamics, in favor of the analytic means used in colloquial Latin, the variant which represented the main agent in the Romanization process.

The specialists showed the reasons of these qualitative evolutions: "First of all, they can be explained by the general tendency in spoken language of using forms as clear and explicit as possible. Secondly, regarding the degrees of comparison, the affective factor is more powerfully involved (...) compared to the synthetic forms, which are fixed and lack expressivity, the analytic forms allowed a greater variety of means of expression" (Wald, 1965, p. 144).

The phenomenon, which was argued with many examples of language samples excerpted from different authors, was considered to be also a means of stylistic diversification: "New adverbs that bring a certain variation, as well as a more detailed signification are introduced to express the degrees of comparison" (Izverna-Tarabac, 2008, p. 150).

The well-known constraints of the classical system did not prove to be strong enough to resist against these challenges. Firstly, the markers of comparative and superlative, which were suffixes in their essence, did not seem to have had a degree of specificity high enough to allow them to persist as inflections; likewise, the language structures that gradation manifests by did not have an adequate frequency which would counterbalance the reduced degree of specificity. In contrast, "the periphrastic constructions with adverbs occurred in spoken language during the entire Latinity" (Wald, 1965, p. 144). They were preferred in Vulgar Latin, because the adverbial lexemes functioned as semantic intensifiers more powerful than the suffixes could have been, even if they were specialised. This happened due to the fact that gradation, in its nature, is a category with a great semantic importance and a weak grammar fixed pattern.

One of the important semantic aspects consists in the fact that, most of the times, any gradation (in Latin only the comparative and the superlative were considered as such) means relating the quality to two 'arguments', as the equalization or hierarchy involve an extra focalization in the context. It must also be pointed out that the inferiority and the equality were expressed by means of the (semi)adverbs (minus, minime, tam...) in Classical Latin. Likewise, the adjectives with a vocalic theme such as idoneus, strenuus... were graded analytically: "Magis est l'adverbe employé normalement en latin classique pour former les comparatifs périphrastiques, comme maxime pour former les superlatifs" (DELL, p. 378). The distinction between the adjectives with a vocalic theme and the others could not be strictly respected in the speaking clichés by the speakers, so the analytic forms extended: "Réservé d'abord a quelques adjectifs, dont le comparatif était inusité (type strenuus, idoneus), il s'est étendu à tous les autres, se substituant au comparatif en -ior, dont la valeur n'était pas nette et allait s'affaiblissant" (ibidem).

The grammarians have recorded many destabilizations of the system: "In time, Latin lost the conscience of the idea of comparative expressed by the suffixes ${ }^{*}$ ero and ${ }^{*}$ tero and it added the suffixes -ior and -ius: inf-er-ior, sup-er-ior, ex-ter-ior, in-ter-ior (from inter-us)" (Bujor \& Chiriac, 1971, p. 50).

Sometimes, the phenomenon of synthetic over-grading developed in a continuous series: "Bien que comportant déjà un suffixe de comparatif, exterus a été doté d'un comparatif exterior, -ius (opposé à interieur) (...) et d'un superlatif extremus (...). Ce superlatif est la forme la plus employé; à basse époque on lui crée un comp extremior (Apul.) et un superl. extremissimus (Tert.); cf. postremissimus" (DELL, p. 204).

Beside the synthetic over-grading, the mobility of the system also presents other aspects recorded by the classical authors' texts and by those belonging to the Christian Latin:

a) Doubling the forms of comparative with adverbs: magis maior, magis suspensior, magis melior, magis locupletior, plus magis, magis irritatior, magis lenior, plus lenior, magis aptior, magis deterior, magis sublimior... (apud Wald, 1965, p. 146).

b) Doubling the forms of superlative with adverbs: maxime liberalissima, maxime gravissimus, maxime pessima, maxime humanissimi, ingens planissima, ingens simillima, valde optimus, nimis uberrima (ibidem). In Christian Latin there can be found many “pleonasms": multum carissime, pulcherrima nimis, 
valde obscurrissimus, valde pessime... (Blaise, 2000, p. 86-87).

c) Using the alternative devices (the synthetic form doubles the analytic one) with the adjectives with a vocalic theme: strenuior, industriior, arduius, perpetuius, assiduior, noxiior, necessarior, exiguior, egregissima, perpetuissima, strenuissimus, vacuissimus, asiduissimus... (apud Wald, 1965, p. 143).

d) Using the comparative instead of the superlative: maior autem harum est caritas; omnium rationabilium infirmius et fragilius animal nos sumus homines (ibidem, p. 145); altior est omnibus illis; omnibus altior sit ille medianus (CR, XII, 25, 26); sapientior pre omnibus, uniquique patria sua carior est (Blaise, 2000, p. 85).

This method represented a solution for the future development: "The origin of the Romance form in which the relative superlative is expressed by the comparative + the article probably can be found in such constructions" (Wald, 1965, p. 145).

e) Replacing the synthetic superlative by the analytic one, by using a great number of adverbs, which made their becoming grammatical instruments difficult: multum, bene, valde, pulchre, oppido, impense, egregie, nimis, fortiter, mirifice... (apud Wald, 1965, p. 144). Among the adverbs used to express the superlative in colloquial Latin, multum seems to have been the most frequent: multum mirabilis, multum tardus, beatus multumque felix, multumque religiosus, multum carrissime... (Blaise, 2000, p. 86); multum dilecta (Stati, 1961, p. 123). It was turned into a basic form in certain Romance languages: molto (it.), muito (port.), molt (old fr.), muy (sp.).

The same use can be found in Aromanian: multu mare, multu bun, multu gione (Caciuperi, 1985, p. 33); multu mintimenu, multu muşatî (Caragiu Marioțeanu \& Saramandu, 2005, p.92).

The diversification also occurs in contemporary Romanian, where many constructions with an adverb + preposition $d e+$ adjective (extrem de, excesiv de...), are used to express the absolute superlative and they present a nuanced expressivity which proves to be an obstacle against their turning into grammatical instruments (cf. GALR I, p. 162).

With the Latin adverb, the terminations in the positive are less important. They are distributed according to the types of adjectives or nouns they attach to (avare, longe, facile, merito, falso, secreto, utiliter, prudenter, breviter, humanitus, penitus, raptim, furtim, privatim...). Most of the adverbs that do not involve conversion and that are not usually involved in comparison are included in this diversity: ferme, presertim, omnino, aliter... Other forms can also occur: frustra, ita, quoque, solum...

In the comparative, all of them adopt the termination of the comparative of neuter adjectives in the singular: crebrius, doctius, fecundius, miserius, pulchrius, sepius, tutius...

In the superlative, the nominal inflection of the Instrumental $-e$ was added after the suffix specific to the adjective synthetic form: aptissime, celerrime, doctissime, fortissime, longissime, pulcherrime, rarissime, sapissime, tutissime...

In spite of these differences, it was noticed that: "The methods of forming the comparative and the superlative are the same as with adjectives" (Wald, 1965, p. 202). This remark is valid especially for the analytic forms in spoken Latin: "Likewise with the adjectives, with the adverbs the analytic comparison using magis and maxime, extended very much, especially in the late period, when the synthetic forms lost their value" (ibidem, p. 203).

\section{Romanian}

Romanian, as well as the other Romance languages, inherited the two values of grading in Vulgar Latin which existed also in Classical Latin: the comparative and the superlative.

A few successive changes occurred:

a) The comparative and the superlative movement towards analytic forms made these meet the analytic forms expressing equality and inferiority. In Classical Latin the latter were not considered to be grammatical forms, still they were pretty frequent, and most of the times they were followed by the object of the comparative, introduced by quam, like the synthetic forms. 
Thus, in expressing the equality, the prototypical adverb was tam, which usually correlated with the comparative adverb quam: non tam preclarus est scire Latine, quam turpe nescire; nibil est tam volucre quam maledictum (DLL, p. 1311); quam malus Homerus, tam bonus Chorilus poeta est (DELL, p. 674)...

The adverb expressing inferiority, minus, is also often used in correlation with quam: nibil minus quam hostem expectare (DLF, p. 839); patria hominibus non minus cara esse debet quam liberi (DLL, p. 826).

b) Within the overall configuration of the system built this way, the two values (comparative and superlative), in addition to the positive, became correlated with the comparative of equality, reaching the position of values of inequality. Compared to the inferiority, they became values of superiority. This corresponds to the fact that inequality involves a polarization, so that, within each of them, the opposition superiority - inferiority occurred: the analytic forms of inferiority were attached to the new analytic forms of comparative which has turned into comparative of superiority. In Classical Latin, the semantic field of grading was represented by the lexical antonymy, such as angustior - largior. As a consequence, the lexical antonymy was replaced by that expressed by means of the instruments (semiadverbs) of the comparative and the superlative (magis - minus): mai ingust - mai puțin ingust; mai larg - mai puțin larg, foarte informat - foarte puțin informat.

c) Romanian has not preserved the classical comparison, realised by supletive forms with certain adjectives, which seemed to have been used also in Vulgar Latin, as it occurs in other Romance languages: bonus - melior (fr. meilleur, sp. mejor, it. migliore, port. melhor...); malus - peior (fr. pire, sp. peor, port. pior, it. peggiore...); parvus - minor / minus (it. minore, fr. moins, sp. menor, port. menor...).

In fact, it is interesting that Romanian took only magis from this system, which is not a proper adverb, as certain lexicologists consider, but a comparative form of magnus, that functioned alternatively together with plus and that was specialised for countable quantities for a while: "magis (arh. mage), adverb in the comparative form (superlative maxime), indicating the qualitative superiority, while plus - the quantitative one (DLL, p. 791); " ${ }^{*} m a g$-is, where -is is known to express the comparative and it can not be anything else but the reduced form of *-yos" (Bujor \& Chiriac, 1971, p. 53).

However, as Romanian did not take minor / minus it used the indefinite pronoun puţin, a variant of Vulgar Latin, which certain lexicographic works consider to have an unknown etymology (DEX, p. 903), but which involves a reconstructed form, ${ }^{*}$ pittinus / putinus (MDA, p. 107; DER, p. 649; cf. sp. pequeño).

This does not represent an explanation of the fact that certain linguists consider the forms of inferiority to be "the attribute of those who use a cultivated variant of Romanian, of those who can speak also Western Romance languages (...). So, the comparative of inferiority (and the relative superlative) can be considered to have a cult origin (French - Italian), to be a recent comparative structure" (Niculescu, 1999, p. 184-185). Still, such forms can be found also in southern dialects: Nî̀î easti ma puţînu bunî di nîsu; Paplu imnî ma puțînu ayonea di maa (Caragiu Marioțeanu \& Saramandu, 2005, p. 180). Besides, its occurrences in Old Daco-Romanian precede the alleged Romance influence.

d) A real challenge for all the Romance languages, in general, and especially for Romanian consisted in dissociation of the relative superlative and the absolute superlative.

In Latin, the opposition was realised contextually: senex omnium sapientissimus (relative superlative), femina pulcherrima (absolute superlative). The superlative forms with prefixes (vir preclarus) did not usually occur with the adverbial of the superlative.

Romance languages used the determination and, as the determination was analytical, the method integrated in the new system very well. Romanian, a Romance language where the article is enclitic (synthetic), adopted more solutions.

Istro-Romanian used an over-segmental method, preserving the identity of the forms and moving the stress from the adjective (mai búr = comparative), to the semi-adverb (mái bur = superlative) (cf. Caragiu Marioțeanu, 1975, p. 200).

Aromanian turned the determination with a definite article into a grammatical instrument: Toma 
easti ma marli di noi; Maria cu Venera sîntu cama bunili feati di Verygia (ibidem, p. 240).

Megleno-Romanian uses the same method as Aromanian (the enclitic article with the adjective in the comparative), but it innovates by adding the formant țel, țea, to it, so it uses the so-called demonstrative or adjectival article: tsela mai marli ra-nsurat (ibidem, p. 279). It must be noticed that, in many situations, the two articles were not used simultaneously, as one of them could be deleted in the expressions.

Daco-Romanian excludes the synthetic determination, which involves the definite article, although in the positive degree its redundant use is quite frequent in old texts: Domnul cel tarele (PH, 23/10); Dumnedzăule tarele, ascultă rruga mea ( $\mathrm{pH}, 83 / 9)$. But the formant cel, cea, cei, cele, gets specialised and only the first element in the masculine/neuter is used for the relative superlative of the adverbs.

\subsection{Degrees of intensity}

\subsubsection{Positive degree}

With the adjective, the positive degree represents the basic form of the adjective and, regarding the grading, it does not present great changes during the evolution of Romanian. It is included in the logic scheme of the category at the same semantic level with the comparative of equality, expressing a quality equal to itself, not being compared to anything else. This is the reason why the comparative of equality can be used without the semi-adverbial expressions of comparison la fel de, tot aşa de... This aspect was pointed out by the linguists: “...the facultative character and the status of the mark of the comparative of equality: the elements la fel de, tot aşa de, tot atât de... are not compulsory and the occurrence of the comparative adverbial does not depend on them" (Zafiu, 2006, p. 216). In such sentences, there is an elliptic comparative, established by the comparison adverbial and not by a "compared positive" (GALR I, p. 155): the positive degree expresses a mere quality, which is not compared.

In Old Romanian the intensive adjectives (cf. Brăescu, 2012, p. 66) amplify their power insistently by means of enumerations with a great number of elements: pre eale luminate, dulci, mirositoare, iuşoare, supțiri (...) sănătoase (Ê̂, 375, 12-13); și alese tot oameni buni și derepți (...) și am făcut țară mare și bună și dulce (A, 6r/6-6 $\left.6^{\mathrm{v}} / 2-3\right)$; Într-acealea zăcea mulți bolnavi, orbi, ologi, uscați ( $\left.\mathrm{TE}, 17^{\mathrm{v}} / 10\right)$; calul rîios, găsește copaciul scorțtos: iuți, mîndri, mincinoși, fățarnici, giurători pentru hiece, amăgitori (LTMN, 309²/4-6); ce și alți mulți împărați bogați, cinstiți, mari, tari și vestiți (co, Div, 12 $\left.{ }^{\mathrm{r}} / 1-2\right) \ldots$

Sometimes, the determiners are in a relation of antonymy: ce feali de omu e: jidov sau păgin, cinstit au ruşinat, derept au păcătos, destoinic au ba, bogat au mişel, cum era și acest sutaş (TE, 63 $3^{\mathrm{r}} / 1-3$ ). They also occur in other diversified correlations: unele era albe, altele roșii, altele mohorîte, verzi sau pestrițe (A, $\left.10^{\mathrm{v}} / 6-7\right) \ldots$

The emphatic demonstrative $c e l$ is used with a similar semantic involvement in three element phrases such as șearpele cel de demult, Domnul cel răstignit (Ê̂, 177, 5; 178, 10), where the middle element can be deleted: şearpele de demult. Considering these reasons, it has been argued that cel "loses its pronoun value (it becomes adjective) and it is assigned the syntactic function of emphatic determiner (like the other demonstrative adjectives placed after the head)" (GBLR, p. 140), "being the typical means of realizing the over-determination" (Brăescu, 2012, p. 85). In certain contexts, the definite article has the same function: scoateți mişelul şi mesearul și den mînrule greșitului mîntuiţi-l ( $\mathrm{PH}, 80$, 4); era următoriu Marelui Petru (PRED, p. 54).

The movement from the value of demonstrative pronominal adjective to the semi-independent pronoun is sometimes evident, when the determiner of the noun turns into the head of the group: cei oameni buni, ei sînt lepădați, iară cei răi sînt în mare cinste (...) el face celor oameni buni dereptate și bine, iar celor răi, rău face ( $\left.\mathrm{TE}, 153^{\mathrm{r}} / 7-8,10-11\right)$.

In this direction of development, "la grammaticalisation de l'article adjectival roumain" (Iliescu, 2006, p. 163) is excluded.

In Old Romanian, the over-determination occurs especially when the adjective has two "articles": Domnul cel tarele ( $\mathrm{PH}, 23,10)$; locul cela strimtul (CLRV, 1, 1 $/ 10)$; dzilele ceale bonile (Cv, 66 $/ 13-14)$; 
soția ta ceaea iubita (Cs, 113 $/ 13-14)$; chinul cela marele (Cs, 114 $\left.4^{\mathrm{v}} / 4-5\right)$; ... The redundant determination can be considered the same: Dumnedzăule, tarele, ascultă rruga mea (PH, 83, 19), marea Arrtemida efeseiască (cv, 6r/10-11); marele patriarhul Ioan Zlataust, invățătorul (cs, 49²/2-4); tatăl putearnicul, făcătoriul ceriului $\left(\mathrm{Cs}, 102^{\mathrm{r}} / 7-9\right) \ldots$

As a pronominal adjective, $c e l$ takes over the marks of gender and number from the noun as a consequence of the agreement. Thus, the marks of masculine singular occur: cel fecior mai mic cu cel mai mare (Ê̂, 26, 10), șarpele cel înfricoșat, chitul cel stricătoriu de suflet (Ê̂, 87, 17-18), legă pre cel tare și birui pre cel viclean (Ê̂, 370, 6-7), spre Dumnedzăul cel tare și cel viu (DPS, 41, 2); feminine singular: lumina cea minunată a preamîndriei cea neajunsă (Ê̂, 334, 14-15), Și casa ce mare și ce mică era plină de turci (LTMN, 300/19-20); masculine plural: pre cei mîndri și falnici (LTMU, 21 $/ 16$ ); Ci nevoie ieste a opri cei puțini pre cei mulți și cei slabi pre cei tari (LTMU, 116\%/14-16); feminine / neuter plural: gol de toate și de ceale trupești și de ceale sufletești (Ê̂, 16, 16); vulpile ceale impuțite (...) vîrtoapele ceale văzute (Ê̂, 282/10, 14); ş-au bulit lucrurele lui ceale bune $\left(\mathrm{TE}, 72^{\mathrm{r}} / 6-8\right) \ldots$

As the head of a group, but also as an emphatic determiner, cel presents case inflections, those of genitive and dative being evident: a lu Dumnedzău celui den sus ( $\mathrm{pH}, 11,6)$; deșchisul trupului lui celui

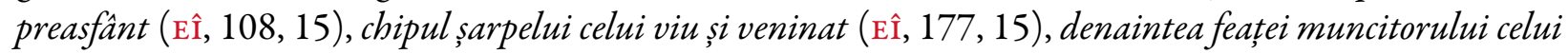
mort $(\mathrm{E} \hat{\mathrm{I}}, 395,3)$, de spuse ceii feate preacurate $\left(\mathrm{Cs}, 2^{\mathrm{v}} / 11\right)$, socotitoriu credinței ceii direapte $\left(\mathrm{VO}_{1}, \mathrm{II}, 4\right)$; din fintîna vieții ceii vecinice (DPS, V, 8); al tainelor celor negrăite (Ê̂, 334, 14); înfricoșare puterilor celor drăcești gonitoare (Ê̂, 185, 11).

With the adverb, the positive degree does not present the diversity of the aspects which occur with the adjective, especially when only those which present the category of grading are approached. Some sentences present the conversion from the adjective: păsărifrumoase era și cînta frumos $\left(\mathrm{A}, 10^{\mathrm{v}} / 5-6\right)$. Most of the times, the verbs are determined: și căuta semeț spre oaste (A, $\left.1^{\mathrm{V}} / 9-10\right)$, iar omul răcni tare și zbieră tare $\left(\mathrm{A}, 2^{\mathrm{r}} / 6\right)$, și să mirară mult (A, 9 $\left.{ }^{\mathrm{r}} / 7\right)$; rău să întristă și cumplit să mîhni (CO, Div, 14 $\left.{ }^{\mathrm{r}} / 5-6\right) \ldots$

\subsubsection{Intensive degree}

It is the middle degree in the configuration of intensity and, although it is often described by the grammarians (cf. Iordan \& Robu, 1978, p. 343; Irimia, 2008, p. 101-102), it has not been individualised so it has not been dissociated from the comparative: on the one hand, the markers of the intensive degree are attached to those of the comparative and, on the other hand, there are means of intensification with the comparative, too. The most recent Academic Grammar describes the intensive constructions and the progressive constructions indistinctly, within the area of the comparative degree (cf. pp. 157, 158), realised by a) mult mai, și mai, incă mai; b) tot mai, mereu mai, din ce în ce mai. In fact, in these series of formants, the first elements belong to the comparative (the structures can be followed by the adverbial of the comparative: Lucrează mult mai bine decit tine); the others belong to the intensive of superiority (= the progressive: Este din cein ce mai informat) and of inferiority (= the regressive: Este din ce in ce mai puțin informat). It can be noticed that the last type of sentences can not contain an adverbial of comparison: *Este din ce in ce mai informat decît tine.

In Old Romanian the intensive constructions of the comparative occur quite frequently, both with the adjective and with the adverb: Unii voru fi luminați, alții și mai luminați, cum grăiește apostolul (cs, 45\% /2-4); Cu multu trăgea mai multu de alalte măsuri (Ĉ̂, 313/23); dară încă mai rea iaste cînd purcede din lipsa și neștiința cuvintelor trebuitoare (co, Ist, 35/16-17), decît dreptul să poate afla altul și mai drept, așe și decît viclianul iaste altul și mai viclian (co, Ist, 40/19-20); iară despre partea sufletului cu multul mai mult nesățios și nesăturat iaste (CO, Ist, 54/11-12); și încă mai mult între alții nu numai arcoasă sprînceneleși a-și rădica (CO, Ist, 58/12-13); își strică obrazul și numele și mai rău de la Poartă (LTMN, 293/11-12); incă și mai mari mulțămită arătă Iordachi lui Antobi-vodă (LTMN, 297/6-7)...

However, it must be added that these constructions belong to the comparative degree, as means of intensifying the comparison.

The constructions that belong to the intensive degree are characterised, as it has already been argued, 
by the impossibility of attaching the adverbial of the comparative.

The most frequent ones are those of superiority (progressive), both with the adjective and with the adverb: Și glasul trîmbiteei ce de ce mai mare se inălța (PO, Ex, 19, 19; cf. lat. et sonitus bucina paulatim crescebat); tot mai spre rău den zi în zi mergînd (RG, 129/2); nu va să ierte păcatulși greșala acești țări tot mai mare și mai rău și mai amar și mai suspin să adaoge (LTMN, 283, 27-29); sirinile tot mai de rău fácătoare (co, Div, 19\% /17); din an în anu tot rău și amar de creștini și pustiire au rămas (LTMN, 222, 17-18); dar, ca să admirați din ce în ce mai mult exactitatea prea strălucitului traducător (PRED, p. 105: foreword by Antim Ivireanul, 1704).

Certain expressions involve the progression by repeating the intensifier: acmu mai mai tot cuvintul să curma (...) și toată gura mai mai să astupa (...) Și acmu cu toatele mai mai după voia Corbului să lăsa (co, Div, 35/18-19). The phenomenon is scholarly, with a Latin model: " 3 (repeated) magis magisque (magis et magis, magis atque magis, magis magis) din ce în ce mai mult" (DLL, p. 792). The iterative adverbial construction did not manage to get to express progression, but it is only an approximating marker (cf. Brăescu, 2012, p. 100) of the action: era mai mai să reușească.

\subsubsection{Absolute superlative}

It is the degree that expresses the greatest intensity of the quality (the absolute superlative) or its least variant ('the negative superlative': Irimia, 2008, p. 101; Dimitriu, 1999, p. 207-208). If the improper name of 'superlative of inferiority' were abandoned, the expression 'inverse absolute superlative' could be used.

During its development, Romanian used ways which existed in Vulgar Latin: the adverbs multum and forte, as well as the superlative prefix prea-. These, "in fact, play the role of some intensifiers" (Gafton, 2001, p. 108).

The adverb multum, which has been continued in some Romance languages, as it has already pointed out, a basic form in Aromanian, was quite often used in Old Romanian, too. Firstly, it was used as adjective and adverb: mumă voastră Cleofila ce fu mult înțeleaptă (A, 56 $/ 9-10$ ); multă fu plîngere tuturoru (Cv, 12 $\left.2^{\mathrm{r}} / 13\right)$; și multă vreame trecu (cv, 43 $\left./ 4-5\right)$; cu multu prețu agonisiiu aceasta cetate (cv, 23 $\left./ 1-2\right)$; și de stîlpurile lor era spînzurați nărod multu (cs, 24 $\left.{ }^{\mathrm{r}} / 7-10\right)$; oile lor multu se-au ploditu ( $\left.\mathrm{pH}, 143,13\right)$; mult imblă sufletul mieu (PH, 119, 6); și mult au hulitu pre slujitorii besericiloru (cs, 25²/13-14)...

The proper absolute superlative was often expressed by this semi-adverb in Old Romanian: multu easte milostiv și ieftinu (cv, 67 /12-13); Că tu, Doamne, bunru și blîndu ești și multu milostiv tuturor (PH, 85, 5); ucide pieptul tău, mult păcătoase suflete; primăvara (...) cea mult roditoare au sosit; iară pre noi, mult milostive Doamne...; sufletul nostru mult roditoriu (Ê̂, 181, 19; 283, 8; 315, 6; 332, 2-3); Dereptu apostoli, rugăm multu milostiv Domnul (cs, 109\%/6-8); Doamne, miluiește-mă că sînt mult păcătos (CPV, 6/3); Ai miei cei mult mînioș / Ce să scoală însetoș (CPV, 17/235-236); numai Dumnedzeu este mult milostiv (LTMN, $\left.215^{\mathrm{v}} / 4\right)$; mult dorita și așteptata sară (CO, Ist, 83/4-5)...

Old Romanian tried an antonymic opposition based on the adjective/adverb putin to express the opposition superiority - inferiority (supreme - insignificant) with the absolute superlative.

Thus, the proper absolute superlative was used to build sentences such as: fu in vreamea acea voroavă nupuțină; da meșterilor lucrare nu puțină; Și aduseră pruncul viu și fu mîngîiare nu puțină; Și varvarii fäcea nu puțină noao milostenie; și căzu frigu nu puținu (cv, $\left.4^{\mathrm{r}} / 12-14,4^{\mathrm{v}} / 4-5,9^{\mathrm{r}} / 1-2,48^{\mathrm{r}} / 11-12,44^{\mathrm{v}} / 6\right) \ldots$ The constructions are very frequent and they occur also in later texts which do not represent translations: nu puțină întristare domnului și neamului au dat; nu puțin vrednic și înțelept; l-au spînzurat unde nu puțin norod era; pre carele nu cu puțină cheltuială l-au ridicat; nu puţin s-au turburat (RG, 144v /14-15, 17, 168/18, 181/4, 191 /9-10); nu puține reale și stricăciuni au simțit ținuturile romanilor; însă nu puţină mirare iaste la toț (ITR, $\left.13^{\mathrm{v}} / 5-6,71^{\mathrm{v}} / 1\right) \ldots$

The fact they are equivalent to the superlative can be noticed both in the Latin text (Aduxerunt autem puerum viventem et consolati sunt non minime, NT, Act, 20,12) and in the following translations: Și aduseră pe fecior viu și să mîngîiară foarte (NTB, Fapte, 20, 12); Iarpe tînăr l-au adus viu și foarte mult s-au mîngîiat 
(в, p. 1263).

The opposite pole, that of minimal intensity, was expressed by antonymy, deleting the negation: Și zise lor Iisus: Ce sînteți spăimați voi, o, puțin credincioși; și grăi lui: puțin credincioase, pentru ce te îndoiși? (NTB, Mat, 8, 26; 14, 31); Ce sînteți fricoși, puțin credincioșilor? (AI, 164v /12).

As the language samples show, the method is quite well represented, extending from the religious translations to other styles. However, because puțin was often used with adjective and adverb value, it could not be maintained.

In Vulgar Latin, the adverb forte replaced the classical adverb fortiter. It can be interpreted as a conversion of the adjective fortis, $-e$, which has its own degrees of comparison: fortior atas, fortior numerus, fortissima ligna, forte et vehemens dicendi genus (DLF, p. 563).

Like magis, in the comparative degree, it occurs alone, as a simple adverb (subsequently it loses this function), involving a superlative intensification more or less (foarte = puternic): Și blagoslovi ei și mulțirăse foarte (PH, 106, 38); Așa și limba, mitiutelu mădulariu easte și foartte se laudă (cv, 62 /7-9); foarte au mîniat pre Dumnezău; se miră de aceasta foarte; Bucură-te foarte, fata Sionului; și ne foarte așa mirăm de podoaba lor (Ê̂, 11, 12-13; 264, 1; 277, 6; 357, 16); ceea ce tu cu nuşii foarte te dezmierdai (cs, 113\% /1516); și sufletul meu să spămăntă foarte; Ferit-au mărturiile tale și îndrăgitu-le-au foarte; foarte am silit de-am pus cuvintele (DPS, $\left.5^{\mathrm{r}} / 3,163^{\mathrm{v}} / 166,211^{\mathrm{r}} / 6\right)$.

The adverb virtos ( $<$ lat. * virtuosus) was often used with a meaning similar to the adverb foarte: intoarcese-vor și sfii-se-vor vîrtos currundu (PH, 6, 11); mai vîrtos de cărturari și farisei; mai vîrtos de toți; mai vîrtos de năsipul măriei (Ê̂, 6, 8; 8, 4; 10, 14-15); ci mai vîrtos cu multă blîndețe (RG, 1, 28)...

One of the fundamental features of the adverb value of foarte was the mobility of its position, which made its becoming a grammatical instrument, a formant of the absolute superlative very difficult.

It often occurs in ante-position, the normal use: focului care era foarte mare; păcatul (...) foarte amar (Ê̂, 13, 11; 31, 17-18); au fost războiu foarte tare și mare (LTMN, 215 /4); Om foarte învățtat, ințtelept bun și ostaş mare era (ITR, 24 /6-7); foarte cu greu iaste a lăsa Beligradul; foarte peste putința săracilor era; dăruind mării sale și un cal foarte frumos (RG, 170v/13; 175, 27-28; 200 $/ 17-18) \ldots$

Still, it is frequently placed after the adjective or adverb: Mare-i Domnul și lăudat foarte ( $\mathrm{PH}, 46,2)$; vestit întru ovreai și bogat foarte; piatra prăvăli că era mare foarte (Ê̂̀, 418, 10; 426, 16); desfrînată domniia și nedireaptă foarte (LTMC, 159, 16); și acolo mult foarte într-însa aur, argint și alte scule (ITR, 19v/4-5); moșii märii sale, care fiind mică foarte (RG, 202 /19-20)...

The most evident obstacle against its becoming a grammatical instrument is the fact that other lexical elements are placed between it and the base-word: loru le pare că foarte umblă bine in porincile lu Dumnezeu ( $\left.\mathrm{TE}, 83^{\mathrm{v}} / 11\right)$; cum am face lor foarte o slujbă mare $\left(\mathrm{VO}_{1}, 27^{\mathrm{v}} / 2\right)$; iară foarte au ținut puțină vreame războiul; foarte este tare și cu nădejde de izbîndă; foarte cu puținte oaste curuți de-a lui rămăsese; ce foarte un lucru puțin; era foarte cu supărare mare oștenilor (LTMC, 165, 1-2; LTMN, 212v/10-11, 380v/11-12; 425, 5); care era foarte om viteaz și meșter la ale războaielor; Sever voievod, ostaş foarte și vreadnic, l-au trimis în Siria (ITR, 13²/11, 163); l-au facut de iznoavă, foarte lucru frumos și minunat (RG, 188v/40).

Similar positions in the sentences occur also with the adverb: Și se bătură foarte tare (A, 2 $/ 3)$; Aicea vedem Hristos să ceară foarte tare credința cea slabă ce avură jidovii (TE, 86 ${ }^{\mathrm{r}} / 1$ ); l-au ospătat dumnealui paharnecul foarte frumos (RG, 200 $/ 17-18)$...

The superlative prefixes, especially pre (a) -, are frequently used.

However, in this respect, it does not exceed the analytic forms realised with the semi-adverb foarte (cf. Frâncu, 2009, p. 272). This prefix was inherited from Latin, where it was very productive, too: "Likewise, Latin used also the compounds with prefixes per and pre. The method seemed to have been specific to spoken variant (...). In the archaic period the forms with pre-occur; they are used in all the periods, up to the late period" (Wald, 1965, p. 143). The Slavic influence consolidated its position. Its availability is so great that it extends to other parts of speech, especially to verbs and nouns: intru putinelu nu me preapîrrești (cv, 41 $\left.{ }^{\mathrm{r}} / 7-8\right)$; aceaste dzile preavestiși (cv, 18 $\left./ 13-14\right)$; Deci o preaîndrăgi și puse ochii hitleni spr-nsa (MO, 22 $2^{\mathrm{r}}$ /5-6); lucrul său întru mîndră preamîndrie (cv, 63 $3^{\mathrm{r}}$ 11-12); să spurcă cu rele lucrure, cu 
preaiubire și clevetescu $\left(\mathrm{Cs}, 12^{\mathrm{v}} / 5-7\right) \ldots$

The prefix is usually attached to the lexeme that is intensified: Cinre e preamindru și meșteru intru voi (cv, 63 /9-11); slava aceasta iaste tuturor preacuvioșilor lui (pH, 149, 9); Spuse ceii feate preacurate că va naşte Hristos? (cs, 2v/11-12); și luară preacinstita maică lu Hristos (cs, 22v/7-9); Aduse oarecine impăratului un măr preamare; De-acii prinseră grecii preamulți; și huliia pre Maica preacurata; proslăviia și precista Maică (Mо, 59 $\left./ 3,75^{\mathrm{v}} / 4-5,91^{\mathrm{v}} / 2-3,102^{\mathrm{v}} / 7-8\right)$; nice preacurvariu ca alalți oameni; Cel preacurat și prealuminat scaun al lui Dumnezeu; și de la prealuminații îngeri a lui Dumnezeu; Acel preaînșălătoriu și fur meșter; va fi de preaminunată vedeare; o, preadulci cuvinte; Preaveacinicul Dumnezeu; Dumnezeu preaveacinic îndoită naștere are (Ê̂, 4, 7; 10, 17-18;27, 7;387, 11; 67, 15;259, 16;304, 10; 387, 11); și cu preacurvariul partea ta o puneai (DPs, 62 r 19); Deci pre dînsul, preafrumos, prealuminos știindu-l (Co, Div, 6r/15)...

Certain transcriptions in the Cyrillic writing place prea detached from the base-word: Și era prea

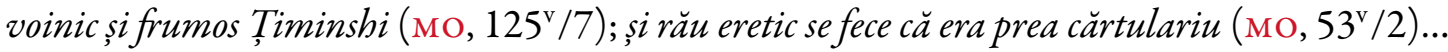

The superlative with prea quite often occurs also with the adverb: preslăvit grăiră-se de tinre ( $\mathrm{pH}, 85 / 3)$; de-și scoase țara pre uşor de foamete (MO, 125\%/2); prea lesne nu va putea cuprinde Ardealul; prea lesne cuprinde orașele pre sama sa; le-a dat leșilor războiu pre tare și frumos, căce merge pre bine și frumos la războiu (LTMC, 163, 16-17; 165, 10-11; LTMN, 247\%/13-14)...

Even in Latin, the superlative degree could be expressed by means of many adverbs functioning as intensifiers. In Old Romanian, as well as in modern Romanian, the adverbial expressions involved in extreme intensifying are very often used. Like in contemporary Romanian, their functionality is complex: "The common element for this semantically heterogeneous and numerous class is the presence of the grading marks, belonging either to a quantity area or to a quality and appreciative signs area, which places all these determiners in a stylistically marked register, one of affectivity and emotions" (Pană Dindelegan, 1992, p. 92).

There are numerous examples in Old Romanian, either with the adjectives or with the adverbs: prespre măsură învrăjbiia ei (cv, 38 /3); și să munciia fără seamă mulți; adul iaste plin de amar fierbinte și durere fără seamă; să va grăi glas de urgie fără de măsură; va zice tuturor Hristos cu glas mare de urgie fără de măsură $\left(\mathrm{cs}, 31^{\mathrm{r}} / 8-8,112^{\mathrm{v}} / 13-15,44^{\mathrm{r}} / 15-44^{\mathrm{v}} / 1-2,111^{\mathrm{v}} / 10-12\right)$; să poată vedea acea făr'desăvîrșit și nespusă mare adincime a facerilor de bine a lui Dumnezeu (AI, 102, 23-24); si pre Dumnezeu carele e intrutot ieftin in veaci (Ê̂, 92, 16-17); cu greutate mare, nesuferită și peste toată putința (RG, 136, 19-20); țara cu dările o ingreuia și era om curvariu preste samă (LTMU, 125 $/ 21-22)$; și aceia era iuți tare, cum nimenea nu putea treace $\left(\mathrm{TE}, 66^{\mathrm{r}} / 6\right)$; ese un feliu de muscă mitiutică (...) și ca roii iase multă fără seamă $\left(\mathrm{AB}, 130^{\mathrm{r}} / 6-7\right) \ldots$

There are also other means of realizing the superlative, but they are less frequent. Firstly, other superlative prefixes must be mentioned. While prea was proved to have been very frequent in Old Romanian (Ocheșeanu, 1959, p. 35), the situation of stră- is different, as it occurs either with the adjectives or with noun conversions: Domnul, străluminătoriul mieu și mîntuitoriul mieu (DPS, 29 / 1-2); se apropie de aromi pe strămoaşa, de-i arătă poamele frumoase ( $\left.\mathrm{MO}, 9^{\mathrm{r}} / 1\right)$.

The method consisting in repeating the adjective is considered to belong to the colloquial register and it occurs also in contemporary Romanian: Acea mare mareși largă, - aciia gadine ce nu li-i numărul, jigănii miciși mari (TE, p. 202).

The superlative realised by internal repetition, such as ceriul ceriului (cf. Arvinte, 2004, p. XXX) has a long history, beginning with the Hebrew pattern and, although it is not very frequent, it was continued in spoken Romanian: sfințitoriu și spăsitoriu și domnedzeuldomnedzeilor; Că acolo sint toate muncile muncilor (Cs, 91 $\left.1^{\mathrm{r}} / 7-8 ; 112^{\mathrm{v}} / 16-17\right) \ldots$

As a result of the scholarly influence, the superlative in the Classical Latin was proposed: Duca de Saxoniea care era ghenerariusemus, adecă mai mare preste toți gheneralii (AB, 134 $\left.{ }^{\mathrm{r}} / 26-27\right)$. 


\subsection{Degrees of comparison}

They are disposed in a three element configuration: the comparative of equality, the comparative of inequality and the relative superlative.

\subsubsection{The comparative of equality}

At the sentence level, it is realised by means of comparative semi-adverbial expressions la fel de (tot aşa de, tot atît de, deopotrivă de), and at the adverbial level by cași, cît, cum (cf. GALR I, p. 156), and it often occurs in texts. But in Old Romanian the semi-adverb is deleted: să vețifi așa ca și noi (po, Gen, 34, 15); au vrut putea da și mişeilor atîta ca și bogatului; și-l îndrăgește, nu intr-alt chip, ce ca și trupul tău și ca sufletul tău (TE, 121 1 /13, 130 /18); Așea-i iubește ca și lumina ochilor săi (Sicriul de aur, apud Dragoș, 1995, p. 108)...

When it is missing, sometimes together with the adjective, the so-called elliptic comparative is realised, and this persists quite often even in the contemporary standard Romanian: suspinru loru e ca prabul inraintea feaței vîntului, ca lutul den cale; și au fost înrima mea ca ceara; ca vecenrului, ca frate nostru așea îngăduiiu, ca plîngîndu și mîhnitu așea mă smeriiu ( $\mathrm{PH}, 17,43 ; 21,15 ; 34,14)$; iubește aproapele tău ca tinre însuți; mînca-va trupul vostru ca focul (cv, 59v/6-7, 66 /12); le părea că Hristos este om prost ca și alți oameni; ca și Petru în muntele Tavorului, așea și Zacheiu $\left(\mathrm{VO}_{2}, 295^{\mathrm{v}} / 21,382^{\mathrm{r}} / 2\right)$; obrazul lui străluciia ca soarele și veșmintele lui era albe ca zăpada; Cine iaste aceasta care să ivește ca zorile, frumoasă ca luna și aleasă ca soarile? (AI, 9, 5-6)...

As it has already been shown, the absence of the adjective or of the adverb makes the respective structures get closer to the modal constructions. Likewise, sometimes the comparative structures reach the area of the quantitative, in various syntactic positions: și atîta era de mare, cît mainte (PO, Gen, 9, 24); să aibă a lua tot finul cit se va afla cosit (AR, p. 114)...

Maybe accidentally and very rarely, the adverbial of comparison expressed by a nominal element is in the nominative, not in the accusative, as the prepositional restriction of decit would impose, when it does not respect the case of the first element: arată și noauo seamne să fim și noi creștini ca și tu (CLRV, 92 /6-7).

At the complex sentence level, the comparative of equality clause is very frequent, it is rarely expresses by juxtaposition: Așa grăiți, așa faceți $\left(\mathrm{cv}, 60^{\mathrm{r}} / 3\right)$. The diversity of the connectors is as great as that in contemporary Romanian.

Thus, in correlative structures cît, precît occur: Năpusti trebile țării, că precît $\hat{\imath} l$ iubea întîi, pre atît $\hat{\imath} l$ urîse apoi; Cîte războaie au bătut, atîte mănăstiri cu biserici au făcut; Ș-așe au lipsit de n-au luat domnia, cît s-ar rumpe un păr (LTMU, 111, 1-2; LTMN, 189, 11-12; 285, 12-13); astăzi acel neam atîta iaste de scăzut, de supus, de hulit și de ocărît și de mojic, cît milă să face tuturor celor ce știind, gîndesc ce au fost și la ce sînt (ITR, 42 $/ 4-5$ ); și precît iaste întăritura, adecă ceriul tău de vîrtos și de mare, aşe nădejdea mea cătră Dumnedzău să fie tare și vîrtoasă (co, Div, 33/11-12); carea, pre cît iaste de adevărată, atîta iaste și de minunată (co, Ist, 80/5-6)...

Cum with its variants is also frequent: Cum vreți să facă voao oamenii, așijderea faceți și voi lor; Cum nu ne teamem de somn și de odihnă, ce ne reposăm cîndu ne culcăm, așa nu ne teamem de moarte ( $\mathrm{TE}, 89^{\mathrm{v}} / 4-5$, 130\% /8-9); Așa am vrut și am svătuit Domniia mea cu călugării noștri (...) cum scrisese la săborul cel dentîiu (CLRV, 64, p. 187-188); Cum trufiia iaste întunearec, așa și smereniia lumină iaste și lucrul lui Dumnezău și de la svințiia lui are începătură; cum sînt caprele sireape, batjocuricioase și put rău (...) așa și păcătoșii îmblă färă frică preste prileazurile a toată färădeleagea (Ê̂, 9/7-8, 69/2-4); că precum ceare împăratul dăjdii de la supușii lui, așa ceare și Dumnezeu de la creștini (PRED, p. 108); nu așa de craiu ascultă, cum de leage care le-au fácut ei; după cum le fusese altă boierie, așe șăde și cu bănia la Divan (LTMU, 44, 17-18, LTMN, 309, 2-3); precum iaste cămilii greu prin urechile acului a întra, încă mai cu greu bogatului în împărățiia ceriului (co, Div, 44 $/ 16-18) \ldots$

The unreal comparative adverbial clause is also very frequent and it is introduced by connectors such as ca și cum, ca șicind, or by those variants accepted by the norm of that period ca cînd, ca cum, ...: derept aceea Dumnezeu slobozi ca slugile popilor să cură cătră el, cum ca și cînd ară vrea să omoară pre el (TE, 32 / 1-3); că după noroc bun, iată, veni și rău ca cum ar fi de la Dumnezău însemnat; ca cum ar lua ei cîrpa unei fämei 
din cap. Așe ține ei că or lua și or bate puterea împărăției turcești; Și așe căde turcii ca cînd ar căde niște pere coapte dintr-unu păr (LTMU, 130v/16-17, LTMN, 355\%/10-11, 359/5-6).

\subsubsection{The comparative of inequality}

As it has already been asserted, it presents the opposition superiority - inferiority. The semantic structure which it represents involves certain fundamental aspects: the comparison between two objects considering a quality (the homogeneous comparison), between two qualities of an object (the non-homogeneous comparison), the degree number comparison (quantitative).

Normally, the elements involved in comparison are arguments. As a result of certain transformations, the direct relation to certain circumstances can be achieved in comparison (the circumstance comparison).

The comparative of superiority. In Old Romanian, in the homogeneous comparison, the comparative semi-adverb mai is generalised. But, it is necessary to mention that its situation is similar to the situation of foarte and some old texts preserve its use as a proper adverb, before it became a grammatical instrument: Mîntuitu-me-au (...) că se mai întăriră decît menre; Vestiiu și grăiiu: mulțiră-se mai decît numărul; Număraiu, mai decît arina mulți-se-vor; veriși mai decît neaua înrălbi-me-voiu; mai decît om bătrîru înțeleș

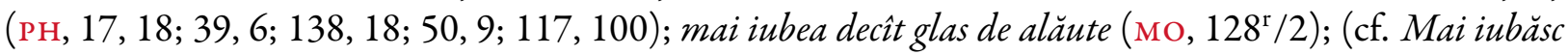
intunearecul decît lumina, apud Zafiu, 2006, p. 218).

The difference was made according to the way the adverbial of the comparative was realised.

The construction with de seems to be the oldest and it is still used in Aromanian nowadays (cf. Caragiu Marioțeanu \& Saramandu, 2005, p. 106): și era mai lung de toți oamenii; nu e nemica mai scumpu de cărturariul și mai curat nu e; și să vede copaciu nalt, mai nalt de toți copacii; să află oameni și mai înțelepți de tine (A, $\left.2^{\mathrm{v}} / 6-7,7^{\mathrm{v}} / 5-6,17^{\mathrm{v}} / 6-7,53^{\mathrm{r}} / 6\right)$; find mai mic de apostoli (Ê̂̀, 14, 3-4); nu vă teamereți amu, de multe pasări mai buni seți voi; cu cîtu e mai bun Dumnezeu de noi... (TE, 129/12-13, 145 /9-10); le va da cununi in capul loru, mai luminate de soarele (cs, $\left.47^{\mathrm{r}} / 15-47^{\mathrm{v}} / 1-2\right)$; Ci noi, mai vechi de acelea nu căutăm (ITR, $\left.8^{\mathrm{v}} / 1\right)$.

The adverb also presents this type of construction: mai vîrtos de toți vrăjmaşii miei fuiu ponosluire vecinrilor miei ( $\mathrm{PH}, 30,12)$; și era inalt, mai sus sta de toți munții $\left(\mathrm{A}, 17^{\mathrm{v}} / 5\right)$; izbindi direptatea noastră mai vîrtos de cărtulari și farisei; mai vîrtos de toți oamenii (...) mai vîrtos de năsipul măriei (Ê̂, 6, 7-8; 10, 13-14); de nu va mai multu de nişte steaguri (...) n-au prinsu (LTMC, 184v/2-3)...

The method is still preserved in Daco-Romanian, in the quantitative comparison: Era lung de 500 de coți și gros de 400 de coți $\left(\mathrm{A}, 9^{\mathrm{r}} / 5\right)$; şi au tăiat atuncea romanii mai mult de 300.000 de ovreai; ci mai multe de șapte, opt (ITR, $\left.25^{\mathrm{v}} / 5 ; 62^{\mathrm{r}} / 2\right)$; ne-au lăsat în citiala istoricilor mai mulți de doi; cu puţine dzile mai mult de 45 de ani însămniadză (co, $H r, 93,7 ; 252,14)$.

The quantitative comparison is far from having a fixed form and it uses also the adverb decit, but there is no chance to fix it in the dominant norm: mai mulți era intr-un loc decit 500 de frați (TE, 36 $/ 5-6)$; au stătut mai mult decît 200 de ani (ITR, 60\% /1); mai mult prețul decît tri mii de pungi de bani (LTMN, 197, 7-8); mare și preaslăvită, mai mult decît trei apostoli (AI, 11, 25-26)...

The most frequent sentences are those where the adverbial of the comparative (of the adjective and of the adverb)follows the dominant use: și muiară-se cuventele lor mai vîrtosu decîtu untulu; mai ugodnic va fi lui Dumnezeu decîtu vițel ce e giuncu (PH, 54, 22; 68, 32); să nu aibi nemică de să-ți fie mai drag și mai scump decît Dumnezeu (Ê̂, 132v/7-8); dorite mai vîrtos decît aurul (...) mai dulce-i decît miiarea și fagurul; mai cinstită decît heruvimii și mai slăvită nepotrivit decît serafimii (DPs, 21 ${ }^{\mathrm{r}} / 11$; 208 $/ 16$ ); mai multu strica loruşi decîtu celor închiși (LTMU, 34 $/ 18$ - 35/1); mai cruzi decît fiarăle ceale nedumesticite (...) și decît aspidele și vasiliscii (ITR, 18 /3-4); mai lesne ar fi cuiva apa curgătoare a popri decît limbilor multe a stäpîni (CO, Ist, 26/2-3); nimic mai vrednic nu era decît pentru mărirea lui (AI, 11, 12-13).

Sometimes, the adverb does not attach to the preposition: să te blagoslovească numele mieu mainte de cîtu voiu muri (PO, Gen, 27/4); numele mai adevărat, mai tocmit, mai alcătuit de cît toate (PRED, p. 53); n-au fost mai josu de cîtu alții (LTMU, 50 /7-8).

Within the same sentence both adverbs of comparison may be used: Mai iubite-s decît aurulu șipiatra 
cea curată multă și mai dulce e de miiarea și fagurul ( $\mathrm{PH}, 18,11)$; face ceva mai mult decît omul și mai sus de ințteleagerea lui $(\mathrm{E} \hat{I}, 308,6) \ldots$

The circumstantial comparison usually involves relating to time and space: $n$-au fost niciodată mai marepustietate în țară decît atuncea (LTMU, 119, 16-17); mai puțină oaste era la Jolkovschii decît la Schinderpaşea (LTMC, 180, 6); și cîndai să nu pață mai rău decît întîiu (LTMU, 18, 10-11).

The non-homogeneous comparison is quite frequent: că scriitorii dentîiu (...) mai mult proști decît să știe carte (LTMU, 3, 2-3); văzîndu-l ei leșinîndu și mai mult mort decît viu (LTMU, 109²/20-21); obicinuită iaste mai mult spre rău și împotriva adevărului, decît spre bine și spre plăcerea adeverinții (co, Div, 46/1819); cărora mai mult oarbă furtună decît buna socoteală le slujiia (CO, Ist, 502/7-8).

In Latin, the non-homogeneous comparison was realised by using both adjectives in the comparative degree: non acrior quam pertinacior impetus; libentius quam verius (DLF, p. 1136).

The comparative of inferiority is little represented. Puţin was quite often used as an adjective or as an adverb, so it has degrees of comparison: pren puțin fuse se mute sufletulu mieu in iadu (PH, 93, 17); leagea lui Dumnezeu, - de-a firea puținei, că sînt puțini aleși și turmă puțină (TE, 15\%/2); micșurași-lpre însul cu puțin oarece de ingeri (DPs, $7^{\mathrm{r}} / 6$ ); dară puțin lucru și puțin ajutor și știință avem de la aceastea; mai pre urmă, puţine greale și reale au ajuns (ITR, $\left.5^{\mathrm{r}} / 7 ; 73^{\mathrm{v}} / 11\right)$; și nu mai puţini apărători decît împotrivitori să afla $(\mathrm{co}$, Ist, 105, 20)...

Some forms with suffixes occur, having the tendency to express the comparison this way (cf. GALR I, p. 165): iar mie puținel nu mi se oborriră picioarele, puținel nu se vărsară urmele meale ( $\mathrm{pH}, 72,1-2) ; C u$ puținel l-ai făcut mai mic pre el de ingeri; carele au fost puținel mai mic de ingeri făcut (NTB, Pav, 2, 7-9); nici puținel nu văd lumina ceriului (Ê̂, 28, 13)...

An important step in its evolution towards a morpheme of inferiority consisted in its use as an adverb determining an adjective, aiming to express the extreme inferiority, as it has already been discussed: puțin credincioase; puțin credincioși (N $\mathrm{NB}, M t, 14,31 ; 16,8)$; puțin socotitoriule (CO, Div, $\left.5^{\mathrm{r}} / 11\right)$, puțin rămași (ITR, 33 $/ 7-8) \ldots$

The next stage is the one of the structure of the comparative of inferiority: cel ce iaste de Dumnăzău cu oarece mai puțin decît îngerii zidit (BB, XXI).

At the complex sentence level, the comparative adverbial clause (with an adjective or an adverb as the element to be compared) differs from the adverbial clause of the comparative of equality with respect to the connectors. The adverb/preposition by which the comparative adverbial is constructed (decit) becomes a conjunction at the complex sentence level: $n$-avăm mai mare grije în ceastă lume decît să întrebăm și să ne invățăm de viiața de veac ( $\left.\mathrm{TE}, 92^{\mathrm{r}} / 24-92^{\mathrm{v}} / 1\right)$; mai bine să moară machidonenii cu cinste, decît să trăiască cu ruşine (A, 26\% /7-8); că mai bine iaste noauă să murim cu Hristos, decît să gonim noi umbra morței în lume (Ê̂, 354, 4-5); mai bine multu va a păzi pe un cetățean și pămîntean de ai lui sănătos, decît ar ucide o mie de vrăjmași (ITR, 56 /11-12); și să fägăduia să le facă bine mai mult decît vor pofti ei (LTMU, 91, 13-14).

Other variants of the connector occur, too: mult mai înnalt și mai slăvit dă cum era mai înnainte (RG, $\left.251^{\mathrm{v}} / 2-3\right)$.

The very frequent use of the infinitive instead of conjunctive can be noticed, which, according to the present rules, turns the adverbial clause into an adverbial: mai bine e a nedejdi pre Domnulu decîtu a upovăi pre giudeț ( $\mathrm{PH}, 116,9)$; Mai lesne iaste cămilei pren lăuntrul urechilor acului a treace, decît bogatul în impărăția ceriului a intra; Că mai scump lucru în ceastă lume nu poate fi cu hasnă și cu folos decît a asculta și a invăța și a ținea cuvintele lu Dumnezeu (TE, 95 $\left./ 9-13 ; 111^{\mathrm{v}} / 15-20\right)$. This situation confirms the theory regarding the evolution of infinitive in Romanian, which was often used in old texts, as well as in Romance languages, as its starting point was Vulgar Latin (cf. Frâncu, 2000, p. 127).

The progressive adverbial clause is also very frequent in old texts: Şi cu cît mai multă avuție dobîndeaște omul, cu atîta și mai mișelu se face; cu cîtu e mai bun Dumnezeu de noi, cu atîta iaste mai bună bogăția ceriului decît a ceștii lumi (TE, 95 /1-2, 145\%/8-9); Cu atîta mai cinstit făcut decît îngerii, cu cît au luat nume mai pe deasupra decît ei; Că cu atîta cinste-i mai destoinic acesta de Moisi, cu cît are mai mare cinste cela ce au zidit 
casa decît casa (NT B, Pav, 291 $1^{\mathrm{r}}$ 4; 292 /3); pre cît mai mult cu cît în oală mai mult fierbe aurul, cu atît mai lămurit iasă; precît prin mai multă vreme acopere, pre atîta mai tare să descopere (co, Ist, I, 73, 16-17); mai multă pedepsindu-mă (...) cu atît mai de frumoasă cunună, podoabă să mă spodobăsc (co, Div, 31 r $/ 4-5$, $7-10) \ldots$

\subsubsection{The relative superlative}

It is usually included among the degrees of comparison because, in a semantic perspective, it is a generalised comparative: carnea noastră este mai dulce de toate cărnile pre lume; cai arăpești, mai frumoși de toți caii pre lume (A, 23v/5-6; 39v/3-4). For this reason, many comparative forms have a superlative value: dar mai rău și mai spurcat și mai varvar și mai tiran nu era alt om pre aceli vremi (LTMN, 282 /8-9); mai tari, mai iuți și mai putincioasă dihanie decît dînșii, alta a fi nu să poate (co, Ist, 2, 10-11).

The second argument for which it is considered to belong to the comparison is the existence of the adverbial of comparison (in Latin syntax this was an adverbial of the superlative). Still, it quite often occurs in an absolute construction and the adverbial is only inferred: Ficiorul tău cel mai mic, Dorif (...) vine și cautăpre cel sol (A, 54 $\left.{ }^{\mathrm{r}} / 4-5\right)$; dzilele annilor noștri (...) iară cei mai mulți ustenită eși lîngoare ( $\left.\mathrm{PH}, 89,10\right)$; Aceasta ce auziiu de la fiul meu cel mai mic și mă umiliu (Ê̂̀, 42, 2); aceasta iaste cea mai mare și mai întîi pricina stricăciunii și a supărării monarbiei romane (ITR, 62 $/ 4-5) \ldots$

The structures of inferiority (the inverse relative superlative) try to become established in Old Romanian: din doao rele cel mai puțin rău alegînd ( $\mathrm{RG}, 135^{\mathrm{v}} / 6$ ); Căci la cei mai puțin domoliți, neputința prinde obrazul putinții (co, Ist, I, 13/7) (cf. also Găitănaru, 2013, p. 46).

The adverbial of the comparative (partitive) is expressed, like in Latin, by the genitive, by intre and din / dintre, and in many situations its presence is possible even if mai or cel are absent (cf. Frâncu, 2009, p. 276): cum au inviat pre fata celui mai-mare al besearecei ( $\left.\mathrm{TE}, 74^{\mathrm{r}} / 24-75^{\mathrm{r}} / 1\right)$; să-i impreune cu cei mai mari ai turcilor ( $\left.\mathrm{AB}, 122^{\mathrm{bisv}} / 11-12\right)$; dintru care tot cea mai puțină parte s-au scris din cîte au fäcut el (RG, 162, 32); De nu te vei cunoaște pre tine, cea frumoasă întru fămei; de la frățior, cea frumoasă în muieri? (B В, Cînt, I, 7; V, 10); carii era mai credincioși din boierii săi (LTMU, 69\% /12).

As it may be noticed, the process of establishing the markers of the generalised comparison, expressed by the relative superlative, had not been over yet.

\section{Concluzii}

The description of the ways adjective and adverb grading manifests pointed out the directions of their development, beginning with the first texts, up to those in the first half of the $18^{\text {th }}$ century. Thus, a basis for relating them with the norm of contemporary standard Romanian has been offered.

These directions of evolution began to manifest in Vulgar Latin, which presented important differences from the Classical Latin and these were continued in every Romance language.

The diachronic description showed the difficult process of turning the markers involved in grading into grammatical instruments, as well as the stability degree of some connectors which are specific to the respective syntactic positions, generated at the sentence and at the complex sentence level. Definitely, it is expected to have a diversification of the nuances by new examples.

\section{Bibliography}

\section{A. Studies}

Arvinte, V. (2004). Normele limbii literare in Biblia de la București (1688), Editura Universităţii „Alexandru Ioan Cuza”, Iaşi. Blaise, A. (2000). Manual de latină creștină, Editura Amarcord, Timișoara.

Brăescu, R. (2012). Adjectivul in română. Sintaxă și semantică, Editura Universității din București.

Bujor, I. \& Chiriac, Fr. (1971). Gramatica limbii latine, Editura Știinţifică, București.

Caciuperi, A. (1985). Gramatică armânească, Freiburg.

Caragiu Marioțeanu, M. (1975). Compendiu de dialectologie română (nord-și sud-dunăreană), Editura Științifică și Enciclopedică, București. 
Caragiu Marioțeanu, M. \& Saramandu, N. (2005). Manual de aromână: Carti trî înviţari armâneaști, Editura Academiei Române, București.

Dimitriu, C. (1999). Tratat de gramatică a limbii române. I, Morfologia, Institutul European, Iași.

Dragoș, El. (1995). Elemente de sintaxă istorică românească, Editura Didactică și Pedagogică, București.

Frâncu, C. (2000). Conjunctivul românesc și raporturile lui cu alte moduri, Casa Editorială Demiurg, Iași.

Frâncu, C. (2009). Gramatica limbii române vechi (1521-1780). Casa Editorială Demiurg, Iași.

GALR I = Gramatica limbii române. I, Cuvântul, vol. coord. de V. Guțu Romalo, Editura Academiei Române, București, 2008.

GALR II = Gramatica limbii române. II, Enunțul, vol. coord. de V. Guțu Romalo, Editura Academiei Române, București, 2008.

Gafton, Al. (2001). Evoluția limbii române prin traduceri biblice din secolul al XVI-lea, Editura Universității „Alexandru Ioan Cuza”, Iași.

Găitănaru, Șt. (2013). Gradația adjectivală: evoluţie, sistem, metalimbaj, în vol. Limba română. variație sincronică, variație diacronică, editat de R. Zafiu, A. Ștefănescu și C. Mârzea Vasile, Editura Universității din București, București, p. 45-52.

GBLR = Gramatica de bază a limbii române, vol. coord. de G. Pană Dindelegan, Editura Univers Enciclopedic Gold, București, 2010.

Iliescu, M. (2006). L'article adjectival roumain; un exemple de récurrence typologique cyclique, în „Revue roumaine de linguistique", IV, p. 159-164.

Iordan, I. \& Robu, V. (1978). Limba română contemporană, Editura Didactică și Pedagogică, București.

Irimia, D. (2008). Gramatica limbii române, Editura Polirom, Iași.

Izverna-Tarabac, I. (2008). Studii de lingvistică, Editura Universității Suceava, Suceava.

Niculescu, Al. (1999). Individualitatea limbii române între limbile romanice. 3, Noi contribuții, Editura Clusium, Cluj-Napoca.

Ocheșeanu, R. (1959). Prefixele superlative în limba română, în SMFC, I, Editura Academiei Române, București, p. $29-51$.

Pană Dindelegan, G. (1992). Sintaxă şi semantică. Clase de cuvinte și forme gramaticale cu dublă natură, Tipografia Universității, București.

Stati, S. (1961). Limba latină în inscripțiile din Dacia și Scytia Minor, Editura Academiei Române, București.

Wald, L. (1965). Adjectivul. Gradele de comparație, în vol. Istoria limbii române. I, redactor responsabil: Al. Rosetti, Editura Academiei Române, București, p. 138-147.

Zafiu, R. (2006). Observații asupra construcției comparative din română, în vol. Limba română. Aspecte sincronice și diacronice, coord. de G. Pană Dindelegan, Editura Universității din București, București, p. 215-225.

\section{B. Dictionaries}

DELL = Ernout, A. \& Meillet, A. (1994). Dictionnaire étymologique de la langue latine. Histoire des mots, Paris, Klincksieck. DEX = Dicționarul explicativ al limbii române, conducătorii lucrării: acad. I. Coteanu, L. Seche și M. Seche, Editura Univers

Enciclopedic Gold, București, 2012.

DER = Ciorănescu, Al. (2001). Dicționarul etimologic al limbii române, Editura Saeculum I.O., București.

DLF = Quicherat, L. \& Daveluy, A. (1922). Dictionnaire latin-français, Paris, Librairie Hachette.

DLL = Guțu, Gh. (2002). Dicționar latin-român, Editura Humanitas, București.

MDA = Micul dicționar academic, $I V$, redactori responsabili: M. Sala și I. Dănăilă, Editura Univers Enciclopedic, București, 2003.

\section{Sources}

A = Alexandria, studiu introductiv, ediție și glosar de F. Zgraon, Fundația Națională pentru Știință și Artă, București, 2006.

$\mathrm{AB}=$ Istoria Țării Românești (Anonimul Brâncovenesc), ediție întocmită de C. Grecescu, Editura Științifică, București, 1959.

AI = Antim Ivireanu, Opere, ediție critică și studiu introductiv de G. Ștrempel, Editura Minerva, București, 1972.

AR = Arhiva istorică a României, vol. 1, 1864-1865, ediție critică de I. Oprișan, Editura Saeculum I.O. București, 2013.

в = Biblia sau Sfinta Scriptură, Editura Institutului Biblic și de Misiune ortodoxă, București, 2008.

в $=$ Biblia adică Dumnezeiasca Scriptură a Vechiului și Noului Testament, Editura Institutului Biblic și de Misiune a Bisericii

Ortodoxe Române, București, 1988.

Cî = Carte cu învățătură (1581), publicată de S. Pușcariu și A. Procopovici, Atelierela Grafice Socec \& Co, București, 1914.

CLRV = Crestomația limbii române vechi, Volumul I (1521-1639), Editura Academiei Române, București, 1994.

Co = Dimitrie Cantemir, Opere, ediție de S. Toma, V. Cîndea, N. Stoicescu, Editura Academiei Române, Univers Enciclopedic,

2003.

$\mathrm{CPV}=$ Teodor Corbea, Psaltirea în versuri, ediție, studiu introductiv, note și glosar de A.-M. Gherman, Editura Academiei

Române, București, 2010.

$\mathrm{CR}=$ Crestomație romanică, vol, I, întocmită sub conducerea acad. I. Iordan, Editura Academiei Române, București, 1962.

Cs = Codex Sturdzanus, studiu filologic, studiu lingvistic, ediție de text și indice de cuvinte de Gh. Chivu, București, Editura

Academiei Române, 1993.

$\mathrm{CV}=$ Codicele voronețean, ediție critică, studiu filologic și studiu lingvistic de M. Costinescu, Editura Minerva, București, 1981. DPS = Dosoftei, Psaltirea de-nțăles, text stabilit și studiu lingvistic de M. Cobzaru, Casa Editorială Demiurg, Iași, 2007. 
Ê̂ = Evanghelie învățătoare (Govora, 1642), ediție, studiu introductiv, note și glosar de A.-M. Gherman, Editura Academiei Române, București, 2011.

ITR = Istoriia Țărîi Rumânești, atribuită Stolnicului Constantin Cantacuzino, ediție critică, studiu filologic, studiu lingvistic, glosar și indice de nume proprii de O. Dragomir, Editura Academiei Române, 2006.

LTMC = Miron Costin, Opere. Letopisețul Țării Moldovei de la Aron Vodă încoace, Cronica polonă..., ediție critică cu un studiu introductiv, note, comentarii, variante, indice și glosar de P.P. Panaitescu, Editura de Stat pentru Literatură și Artă, 1958.

LTMN = Ion Neculce, Opere, Letopisețul Țării Moldovei și $O$ samă de cuvinte, ediție critică și studiu introductiv de G. Ștrempel, Editura Minerva, București, 1982.

LTMU = Grigore Ureche, Letopisețul Țării Moldovei, ediție îngrijită, studiu introductiv, indice și glosar de P.P. Panaitescu, Editura de Stat pentru Literatură și Artă, 1955.

MO = Mihail Moxa, Cronica universală, ediție critică, însoțită de izvoare, studiu introductiv, note și indici de G. Mihăilă, Editura Minerva, 1989.

NT = Novum Testamentul Graece et Latine, ed. K. Aland și B. Aland, Deutsche Bibelgesellschaft, Stuttgart, 1984.

NTB = Noul Testament 1648, Editura Episcopiei Ortodoxe Române, Alba Iulia, 1988.

PH = Psaltirea Hurmuzaki, studiu filologic, studiu lingvistic și ediție de I. Gheție și M. Teodorescu, Editura Academiei Române, 2005.

PO = Palia de la Orăștie (1682), text stabilit și îngrijire editorială de V. Arvinte, I. Caproșu și Al. Gafton, Editura Universităţii "Alexandru Ioan Cuza" Iași, 2005.

PRED = Predoslovii, antologie și cuvânt înainte de T. Nedelcea, Editura Scrisul Românesc, Craiova, 1994.

RG = Radu logofătul Greceanu, Istoria domniei lui Constantin Basarab Brîncoveanu voievod (1688-1714), studiu introductiv și ediție critică întocmite de A. Ilieș, Editura Academiei Române, 1970.

TE = Coresi, Tâlcul evangheliilor și Molitevnic rumânesc, ediție critică de V. Drimba, cu un studiu introductiv de I. Gheție, Editura Academiei Române, București, 1998.

$\mathrm{vo}_{1}=$ Varlaam, Opere, Răspunsul împotriva Catibismului Calvinesc, ediție critică, studiu filologic și studiu lingvistic de M. Teodorescu, Editura Minerva, București, 1984.

$\mathrm{vO}_{2}=$ Varlaam, Opere, Carte românească de învățătură, Răspunsul împotriva Catihismului Calvinesc..., alcătuire, transcriere a textelor, note și comentarii, glosar și bibliografie de M. Neagu, Editura Hyperion, Chișinău, 1991. 